\title{
Public R\&D and Science - Industry Links in Economic Development: Implications for Bosnia and Herzegovina
}

\author{
Slavo Radoševič*
}

\begin{abstract}
The paper presents the current understanding of the role of public R\&D in economic growth and the science-industry links from middle-income economies like Bosnia and Herzegovina $(\mathrm{BiH})$. In the second part, we present the conventional view on science-industry links which see these linkages primarily in terms of a one-way transfer of knowledge or its commercialisation from R\&D to the business enterprise sector. Based on the comparative data, which also includes $\mathrm{BiH}$, we show an alternative approach and argue about its relevance in the context of $\mathrm{BiH}$. Our conclusion is that science-industry links (SIL) should support technology upgrading and not (or not only) R\&D based growth.

In the next section, we present the current understanding of the role of public R\&D in economic growth. Section two explores the role of public R\&D in the catching up context, while section 3 explores specifically the role of science-industry links in catching up context. Section 4 proposes a 'Triple Helix' approach to science - industry linkages for catching up economies. We illustrate its features within the data for the central and east European economies. Finally, section 5 concludes with implications for $\mathrm{BiH}$.
\end{abstract}

Key words: Research \& Development; Science industry links, 'Triple Helix', Technology Upgrading

\section{The role of public $R \& D$ in economic growth ${ }^{1}$}

A conventional argument for public R\&D investments and especially for public support to private R\&D is based on the assumption that firms do not invest in R\&D due to possible 'knowledge leakage'. As a result, firms have difficulties appropriating all benefits of R\&D and, as a result, underinvest in R\&D, which justifies public R\&D or public support to private R\&D.

\footnotetext{
* Prof, University College London. E-mail: s.radosevic@ucl.ac.uk

${ }^{1}$ This section partly draws on Radosevic S (2016) The role of public research in economic development, Chapter II.1 in EC, Science, Research and Innovation performance of the EU. A contribution to the Open Innovation, Open Science, Open to the World agenda, DG for Research and Innovation, European Commission, pp119-139.
} 
The primary analytical evidence on the role of public R\&D in economic growth is the econometric literature on returns to $\mathrm{R} \& \mathrm{D}$. This literature can be divided into:

- estimates of private rates of return on $R \& D$,

- estimates of social rates of return on $R \& D$, and

- estimates of returns to public R\&D

\subsection{Estimates of private and social rates of returns}

Measuring rates of return to $\mathrm{R} \& \mathrm{D}$ are based on the logic of production function, where R\&D is treated as one of the inputs in addition to capital and labour. This approach dominates as it can give quantitative estimates of how much $R \& D$ contributes to the growth or what are returns to $R \& D$ investments.

Estimates of social rates of return on $R \& D$ are based on the assumption that returns from $R \& D$ do not accrue only to inventor but also to other firms in the same industry. This is because these firms are either connected through value chains (suppliers and buyers) or to competitors who can learn freely based on leaders' mistakes or imitate them. The social rate of return is then estimated by adding the private rate of return (the benefit to the firm that performs the R\&D) to the sum of the returns on $R \& D$ performed by external agents, be it other firms or industries or countries.

There is agreement that private and social return rates to privately funded R\&D are significant and positive in many countries. Most of them fall in the range between (10\%)20\% and (30\%)50\%. Social returns to R\&D are substantial and exceed private returns by a considerable margin ${ }^{2}$. They exceed the private return by 50 to 100 per cent. Sveikauskas (2007) suggests that the private return to $R \& D$ is around 25 per cent, while the social return is 65 per cent.

At the macro level, the OECD (2003) study shows a clear positive linkage between private sector $\mathrm{R} \& \mathrm{D}$ intensity and growth in per capita gross domestic product (GDP) for OECD economies. However, there is no clear-cut relationship between public R\&D activities and growth, at least in the short term (ibid). Authors point out that this is due to important interactions between public and private $R \& D$ activities as well as difficult-to-measure benefits from public $R \& D$ (e.g., defence, energy, health and university research)

\footnotetext{
${ }^{2}$ For list of references to these sources see Radosevic (2016) The role of public research in economic development, Chapter II.1 in EC, Science, Research and Innovation performance of the EU. A contribution to the Open Innovation, Open Science, Open to the World agenda, DG for Research and Innovation, European Commission, pp. 119-139.
} 
from the generation of basic knowledge that provides technology spillovers in the long run' (OECD, 2003) .

\subsection{Estimates of returns on public R\&D}

Estimates of returns to public R\&D are fraught with several methodological complexities. First, the direct effects of R\&D are less important than its indirect effects, which occur when investments in the private sector complement results of public R\&D. Second, not all public R\&D should be counted as investments, as for much of public R\&D it is not easy to attribute the rate of return. So, only a small proportion of the public R\&D should be classified as an investment (Sveiruskas, 2007). Third, public R\&D enables or makes possible further investments in R\&D by the private sector. In that respect, it is pretty ambiguous to separate private from public investments as if they were independent of each other if public research establishes basic understanding and concepts while private R\&D implements them. So, this dual nature of public R\&D, whereby part of it does not have commercial aims while other parts create the basis for future commercial developments, makes it quite tricky to interpret estimates of returns from publicly funded R\&D.

A stylised fact of econometric research is that rates of return on public R\&D are lower or less significant than those on private R\&D. For example, see Griliches, 1986; Levy and Terleckyj, 1989; Lichtenberg and Siegel, 1991; Mansfield, 1980; Nadiri and Mamuneas, 1994 and references cited in Hall et al. 2010, Sveiruskas, 2007 and Kokko et al. (2015) ${ }^{4}$. Explanations for these results are different. First, a conventional explanation is that private firms may be less efficient when using public funding to do $R \& D$, or this funding may be far from market research. Second, government R\&D is implemented in areas which are either far from the market (defence) or operate in a mixedmode like health. Third, public R\&D is not to generate direct benefits but indirectly by developing the basis for the R\&D activities of firms and public organisations (universities, hospitals, etc). Fourth, it is often stated that public $R \& D$ is directed towards more risky areas, which should reduce the rate of return. However, when successful, returns on basic $R \& D$ are higher when compared to returns on applied or development R\&D (Griliches, 1986; Link,

\footnotetext{
${ }^{3}$ Park (1995) also found private-sector R\&D to be more important than public R\&D in OECD-based growth regressions. See PARK, W.G. (1995), "International R\&D Spillovers and OECD Economic Growth”, Economic Inquiry, Vol. 33, pp. 571-91.

${ }^{4}$ For full list of references see Radosevic (2016) op cit.
} 
1981; Mansfield, 1980). Fifth, there may be overinvestment by governments into S\&T areas, which are 'overcrowded' and where returns are low. Also, we should bear in mind that there are significant differences in which industries rely on public science. For example, Marsili (2001) shows that contribution of academic research to industries measured by citations to scientific papers in patents can be very high, like in pharmaceuticals and computer industries. In other industries, this type of contribution is low but steady, mainly through the flow of students.

\subsection{Classification of benefits of public research}

Although the econometric approach dominates the assessment of effects of $\mathrm{R} \& \mathrm{D}$, including public $\mathrm{R} \& \mathrm{D}$, it is evident that the complexity of the relationship between public $R \& D$ and growth requires alternative approaches. We know that the links between public-funded $R \& D$ and industry are varied and indirect. Based on these assumptions Martin et al., (1996) and Martin and Salter (2001) (see also Martin and Tang, 2006) have developed a classification of benefits of public research, which shows the variety and complexity of its impacts. These benefits may also accrue from private research, although in probably somewhat modified form and scale. They distinguish the following types of benefits (p. 520):

1. Increasing the stock of useful knowledge;

2. Training skilled graduates;

3. Creating new scientific instrumentation and methodologies;

4. Forming networks and stimulating social interaction;

5. Increasing the capacity for scientific and technological problem-solving;

6. Creating new firms.

\section{Increasing the stock of knowledge}

Public R\&D increases the stock of knowledge, which is available to firms. Publications represent an essential source of learning for firms in sectors like pharma, but it is knowledge, not only information, that is the most valuable to firms. Since public research is far away from the market, it stimulates and enables firms to focus on near-market research, thus being a complement rather than a substitute. This requires familiarity with publications and informal contacts, joint R\&D and networking (Arundel et al., 1995). 


\section{Skilled graduates}

Skilled graduates are in many industries seen as the primary benefit that flows to firms. They bring complex problem-solving skills, new methodologies and the capacity to perform R\&D. Of course, this transfer varies across areas and is dependent on where the critical competencies in specific technology areas reside

\section{New instrumentation and methodologies}

Instrumentation actively drives scientific progress (De Sola Price and Bedini, 1967). Therefore, the development of new instrumentation and methodologies are an essential outcome of public $R \& D$, especially in some sectors.

\section{Networks and social interaction}

Industries are also social communities within which academic networks can play a vital role and are an essential part of technology networking. Links with the academy are essential in industries, which are directly dependent on science. In other cases, where graduates are an important source of new knowledge, networking is a more informal type through alumni. In other sectors, networks are maintained mainly through exhibitions and conferences. Martin and Salter (2001) review literature that shows the intense localised nature of R\&D collaborations, which are reflections of either geographical, cultural or institutional proximity.

\section{Technological problem-solving}

The problem-solving capabilities of the public R\&D sector complement its role as a provider of general scientific knowledge. This expertise is embodied in individual contracts and collaborations with universities and PROs with individual firms and is very frequent in applied $R \& D$ areas.

\section{Creation of new firms}

The creation of new firms through spin-offs is seen as one of the significant or desirable benefits of public R \& R\&D. Despite all policy hype; this seems to be the much less significant benefit of public R\&D (Brown and Mason, 2014).

There are wholly unrealistic expectations regarding the capacity of public R\&D to generate patents, licensing income and research spin-offs based on 
a patent. Only a few universities worldwide have successfully transformed research into innovation, and the majority of revenue from these activities originated from very few universities ${ }^{5}$.

\section{Role of public $R \& D$ in the catching up context}

In this section, we address the question: what is the relevance of literature on rates of returns of $\mathrm{R} \& \mathrm{D}$ for catching-up countries whose firms by and large operate 'behind technology frontier'?

First, research on estimated return rates implicitly assumes that firms' R\&D capability is not an issue. However, this is not the case in catching-up economies where the percentage of permanently $\mathrm{R} \& \mathrm{D}$ active companies is significantly smaller. Second, equally, it is assumed that capabilities in the academic sector enable regular interaction with the business sector and that these interactions can be measured via R\&D budgets. However, the academic sector may not be able to engage in interaction with the business sector for various reasons, including gaps between knowledge bases of public R\&D organisations and enterprises. Hence, the absorptive capacity of the business sector cannot be taken for granted.

Our first point of departure for understanding the role of public R\&D in development in catching up context is that its role should be seen in three sources of $R \& D$ and development: private $R \& D$, public $R \& D$ and $R \& D$ from abroad. The relative importance of these sources varies across development. In the catch-up stage, foreign links are the key, but in post catch-up these are not sufficient, as they need to be supplanted by a variety of local linkages (Albuquerque et al., 2015).

A second departing point is that the role of public R\&D can be understood only when considered in relation to firms' changing capabilities (Albuquerque et al., 2015). So, we need to consider the evolution of both local public R\&D as well as of local firms. In addition to the capabilities of firms, we should also consider the "capabilities of universities" (Eun et al. 2006) or "academic

\footnotetext{
${ }^{5}$ For example, in Europe, $10 \%$ of universities account for $85 \%$ of the total income generated by inventions. UK universities make only $2-4 \%$ of their external income out of patenting and licensing, whereas much larger funding comes from contract research, collaborative research and professional education. In the United States, MIT generates 22 spin-offs a year, whereas the average number among 157 universities is 4 spin-offs. Source: OECD (2013) Commercialising Public Research. New trends and strategies, Paris
} 
capabilities" (Liefner and Schiller, 2008) as they also evolve by becoming more diverse ${ }^{6}$.

It is essential to look at the relationship between public R\&D and the business sector in evolving context. 'As the capabilities of firms, universities, and public research institutes evolve, the nature, the channels, and the reasons for the importance of universities to firms change' (Albuquerque et al., 2015)

We have learned from the historical accounts of public R\&D that channels of interaction between public R\&D and business have historical evolution (Albuquerque et al., 2015). Daniel Schiller and Keun Lee (2015) outline the pattern of changing relationships between academy and business. Initially, universities and PROs provide human resources, testing, and simple problem solving (e.g., consultancy and technical assistance). Later, universities and PROs become better equipped, and local firms may use their laboratories. Finally, they undertake research activities that substitute and complement research and development (R\&D) by firms. There is a similar process on the side of firms. 'Initially, firms may only use university-trained human resources, later they may look for universities and PROs to solve technical problems, and as these problems become more complex, research issues may arise, and $R \& D$ joint projects may become part of the agenda (p.21)' (Kruss et al., 2015)

Historical evidence shows that research at universities and public laboratories which interacts with firm capabilities is one of the significant drivers of catch-up processes (Mazzoleni and Nelson, 2007). However, R\&D programs that effectively contributed to catch-up did not operate within "ivory towers" but were oriented to help solve problems and advance technology relevant to a particular economic sector. By and large, these were the applications-oriented sciences and engineering disciplines where science could directly interact with the problems and opportunities in agriculture, medicine and industry. Finally, in addition to universities, it was also public research organisations (PROs) located outside of the mainline university structure, in dedicated applications-oriented laboratories, which played an important role

Within this perspective, benefits of public R\&D have a somewhat different ordering in the catching up context compared to technology frontier

\footnotetext{
${ }^{6}$ Liefner and Schiller (2008) define academic capabilities as 'the set of functional skills and organizational ability of a country's higher education institutions to carry out their extended role in the process of technological upgrading and learning (p.281)'. The academic capabilities form part of country's absorptive capabilities or external dimension of firms' internal absorptive capabilities.
} 
economies. The following sequence reflects the decreasing importance of different types of benefits in catching up or converging countries ${ }^{7}$ :

1. Training skilled graduates; Training of skilled graduates is probably the most important benefit of public R\&D, especially as firms are not enough advanced to offer the acquisition of required skills on their $\mathrm{own}^{8}$.

2. Increasing the capacity for scientific and technological problemsolving; ${ }^{9}$

3. Forming networks and stimulating social interaction ${ }^{10}$;

4. Creating new scientific instrumentation and methodologies ${ }^{11}$;

5. Increasing the stock of useful knowledge through contract research ${ }^{12}$;

6. Creating new firms ${ }^{13}$.

\section{Science-industry links in the catching up context}

It is usually assumed that science-industry links are pretty undeveloped in the catching-up context like that of $\mathrm{BiH}$. However, research in Albuquerque et al. (2015) and evidence from the EU disproves this (see Radosevic, 2016). First, evidence from innovation surveys in catching-up economies shows that innovative firms regard universities as highly important sources of information to a similar or even higher extent than in developed countries. For example, in the 2008 Brazilian innovation survey, 6.8\% of innovative firms regarded universities as highly important sources of information. In a Community Innovation Survey conducted by the EC, this ratio was $4.3 \%$ (Albuquerque et al., 2015). Also, there is no significant difference between developed and developing countries in ranking by firms regarding the importance of sources of innovation. For example, the correlation in the importance of sources of

\footnotetext{
${ }^{7}$ In footnotes we provide suggestions for possible research projects which could try to depict the extent of these linkages via statistical indicators. Of course, the first best option would be to conduct dedicated survey on the extent of these benefits.

${ }^{8}$ This dimension can be proxied by WEF GCR data on quality of education as proxy for quality of training of skilled graduates

${ }^{9}$ This dimension could be captured by data on funding from BES of HES/GOV RD and data from innovation survey on sources of information for innovation - universities and PROs

${ }^{10}$ This dimension can be captured by data from innovation surveys on sources of information for innovation

${ }^{11}$ This dimension can be captured by data on investments in R\&D

${ }^{12}$ This dimension can be captured by data on papers and patents from HES and PROs, if available

${ }^{13}$ This dimension can be grasped based on data on publicly funded venture capital
} 
information for innovation between the US and India is 0.886 (table 5.6 in Albuquerque et al., 2015).

Evidence like this question the prevailing notion that in the catching-up countries public - business R\&D links are missing or weak. We think that this myth is widespread as the relation between public R\&D and the business sector has been reduced on the commercialisation of R\&D. Indeed, from that perspective, links between science and business are weak in countries behind the technology frontier. However, this is quite a reductionist view on the role of public R\&D. This view stems from the evidence in technology frontier regional contexts, which led to the Triple Helix movement. The underlying idea is that the nature of knowledge in new industries has changed so that it requires new forms of science-industry interactions where their roles are much more overlapping ${ }^{14}$. However, as rightly pointed out by Eun et al. (2006), these industries form the minority of the technology spectrum in catching-up economies. For evidence on CEE, see Radosevic et al. (2010).

Thus, the evidence shows the importance of non-R\&D innovation activities and that innovation policy in many CEE countries is heavily biased towards the promotion of only R\&D based growth. However, R\&D investments by themselves may not lead to innovation for a variety of structural factors. First, R\&D may be far from the market, and thus, although the R\&D system can be internationally excellent, local industry may be unable to commercialise R\&D outputs. Elsewhere this has been described as the gap between international excellence and local relevance (Radosevic, 2011) ${ }^{15}$. Second, R\&D is often not the primary source of innovation, but innovation emerges through non-R\&D innovation modes. Figure 1 depicts the economy as the locus of multiple modes of innovation broadly defined.

Innovation takes place not only based on $R \& D$ but also there's a variety of 'doing-using-interacting' type of innovations that are experience-based (Lorenz and Lundvall, 2006). Growth and productivity of the economy may rest on a variety of other activities which are not innovation activities in a narrow sense or are incremental innovations (product and process engineering improvements). Also, a variety of productivity-enhancing activities, such

\footnotetext{
${ }^{14}$ See Etzkowitz, H., Leydesdorff, L. (Eds.), 1997. Universities and the Global Knowledge Economy: A Triple Helix of University-Industry-Government Relations. Pinter, London.; Etzkowitz, H., 1998. The norms of entrepreneurial science: cognitive effects of the new university-industry linkages. Research Policy 27, 823-833.; Etzkowitz, H., Leydesdorff, L., 1999. "The future location of research and technology transfer". Journal of Technology Transfer 24, pp. 111-123.

${ }^{15}$ Radosevic (2011) op. cit.
} 
as quality-related activities, and other activities like management practices focused on production may drive the growth of added value or productivity (Bloom and Van Reenen, 2010). However, these activities may often be much more critical for productivity growth, competitiveness and employment than R\&D. Instead, R\&D is often important as a promoter of absorptive capacity, i.e. as an activity that helps companies and the R\&D sector to follow trends in $\mathrm{R} \& \mathrm{D}$ and enhance capacity to adapt imported technologies.

\section{Figure 1. The economy as the locus of multiple modes of innovation}

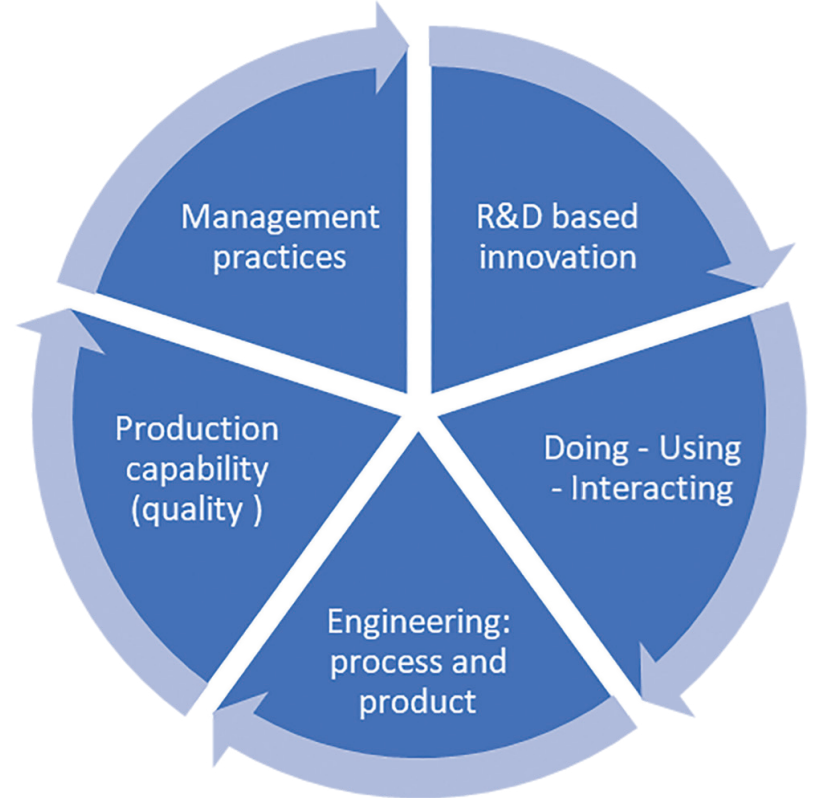

Source: Dominique Foray, Kevin Morgan and Slavo Radosevic (2018) The role of smart specialisation in the EU research and innovation policy landscape, EU Directorate-General for Regional and Urban Policy, Working Paper, Available at: http://ec.europa.eu/ regional_policy/sources/docgener/brochure/smart/role_smartspecialisation_ri.pdf

The 'Doing - Using - Interacting' mode of innovation is important both in developed and less developed countries and yet it is a much-neglected mode. The productivity of economies like Serbia is driven much more by a variety of non-R\&D activities. The three most important are: engineering, production capability and management practices. Unfortunately, data on these activities is sparse. Finally, even when companies innovate, most of their expenditures are about the acquisition of machinery and equipment.

It is important to recognise that these activities are mutually complementary and cumulative. Successful firms are those that couple R\&D based and DUI modes of innovation. Developed production capabilities and engineering 
improvements (incremental innovations) are prerequisites for more ambitious innovation efforts. Improved management practices are also strongly correlated to levels of productivity of firms and economies. So, innovation policy cannot be reduced to $\mathrm{R} \& \mathrm{D}$ based innovation but needs to recognise and address the diversity of innovation modes and productivity-enhancing activities. Hence, the R\&D policy needs to be complemented by measures that address a variety of other equally important sources of innovation and productivity growth.

The alternative way to conceptualise these issues is to assess the extent to which policy addresses the entire spectrum of firms' technology and production capabilities through the so-called 'competence staircase' or 'innovation ladder' (Figure 2). We can only assume that in $\mathrm{BiH}$, these stairs are pretty steep, i.e. the share of research performers in BES is very limited, and the share of companies with technological competencies is also small.

Figure 2: Segmenting enterprises on the innovation ladder

\begin{tabular}{|c|c|c|c|c|}
\hline & & & $\begin{array}{l}\text { Research } \\
\text { Performers }\end{array}$ & $\begin{array}{l}\text { - - research department or equivalent } \\
\text { - - able to take a long-run view of technological } \\
\text { capabilities }\end{array}$ \\
\hline & & $\begin{array}{l}\text { Technological } \\
\text { Competence }\end{array}$ & & $\begin{array}{l}\text { - - multiple engineers } \\
\text { - - some budgetary discretion } \\
\text { - - able to participate in technology networks }\end{array}$ \\
\hline & $\begin{array}{l}\text { Minimum- } \\
\text { Capability } \\
\text { Companies }\end{array}$ & & & $\begin{array}{l}\text { - - one engineer } \\
\text { - - able to adopt/adapt packaged solutions } \\
\text { - - may need implementation help }\end{array}$ \\
\hline $\begin{array}{l}\text { Low-Technology } \\
\text { SMEs }\end{array}$ & & & & $\begin{array}{l}\text { - - no meaningful technological capability } \\
\text { - - no perceived need for this } \\
\text { - - maybe no actual need }\end{array}$ \\
\hline
\end{tabular}

Source: De Jager D. et al. (2002), Competence Centre Programme Estonia Feasibility Study, commissioned by the Division of Technology and Innovation, Ministry of Economic Affairs and Communications of the Republic of Estonia, Tallinn.

It is not surprising that we know much more about the R\&D system and R\&D based growth issues than about non-R\&D innovation activities. Hence, there is a strong need to explore these activities as only when new data are available on these 'hidden innovation' activities, we will be able to legitimise and support policy activities. A standard 'horsework model' in this area which links R\&D, innovation and productivity is the so-called CDM model which can be tested on the BiH BEEPS data or other data which could combine 
innovation survey data with other enterprises level data ${ }^{16}$ (Box 1). This research would show what are limits of CDM model in the economies like BiH? Is innovation the sole driver of productivity? Which are other determinants of productivity? This would also be an opportunity to try to econometrically test alternative or modifications to this model, which is not based on R\&D as the significant input but on variables like investments and which would be based on the synthetic indicator of technology upgrading based on a combination of questions from innovation surveys. ${ }^{17}$ The results of this model would shed much more analytical light on the relevance of $R \& D$ to productivity than it is possible in this descriptive survey.

The second line of research should be based on a firm level survey and would consider the whole range of their innovation activities as depicted in figure 2 .

\section{Box 1: What is CDM Model?}

A so-called CDM model is how economists explore the relationship between R\&D, innovation, and productivity at the firm level. CDM model is based on a three-step sequence.

- In the first step, firms decide whether and how much to invest in R\&D. Only if the net returns to this investment (which the analyst cannot observe, but firms know) are positive will they have positive $R \& D$ expenditure.

- In the second step, the model relates the given investment in R\&D to innovation outputs, defined either as innovative sales or as the number of patents, using a knowledge production function.

- Finally, in the third step, CDM estimates the production function that describes the relationship between innovation output and productivity.

For a summary and application of the CDM model in the context of the CEE/CIS, see EBRD Transition Report 2014: Innovation in Transition, chapter 2, pp. 31-42.

\footnotetext{
${ }^{16} \mathrm{CDM}$ name is coined from the initials of the three authors of the model: Crépon, B., E. Duguet and J. Mairesse (1998), "Research, Innovation, and Productivity: An Econometric Analysis at the Firm Level", Economics of Innovation and New Technology, 7(3), pp. 115-156. ${ }^{17}$ For some of ideas that can be used in developing alternative variables see table 2.2, Golderbg et al (2011), Igniting Innovation. Rethinking the Role of Government in Emerging Europe and Central Asia, World Bank, Washington
} 


\section{4. 'Triple Helix' approach to science - industry linkages for the catching-up economies}

The conventional approach to science-industry links (SIL), which reduces these links to commercialisation of public $R \& D$, is far too narrow and macroeconomically marginal for the catching-up economies. As pointed above, the role of public research organisations can be understood only in relation to firms' changing capabilities. This has been confirmed by a broader examination of these linkages in emerging economies (see Albuquerque et al., 2015). As firms' capabilities, universities, and research institutes upgrade, the nature of the linkages between universities and firms changes.

Also, in addition to the domestic industry-science linkages, we need to consider links between FDI and domestic firms and between FDI and domestic universities and research institutes. Why? In the catching-up economies, the main inflow of knowledge comes through FDI and trade relationships in supply chains (subcontracting) and exporting. Also, public research organisations can access international knowledge networks through international projects, including Horizon Europe or Erasmus exchange programs.

Domestic firms rely on foreign knowledge sources in licensing and reverse engineering or collaboration with customers and parent companies. However, as countries upgrade the importance of local sources of knowledge, including R\&D, increases. Initially, local knowledge is used as a complement to the core technological knowledge from abroad. As countries upgrade, importance of domestic links increases.

So, the SIL should be seen in this context of firm and R\&D system capabilities and their relationship with foreign partners. Figure 3 depicts in stylised manner the actual Triple Helix model in catching up economies which is of high relevance for countries like $\mathrm{BiH}$. 
Figure 3: Triple Helix model of innovation and science industry linkages in catching-up economies

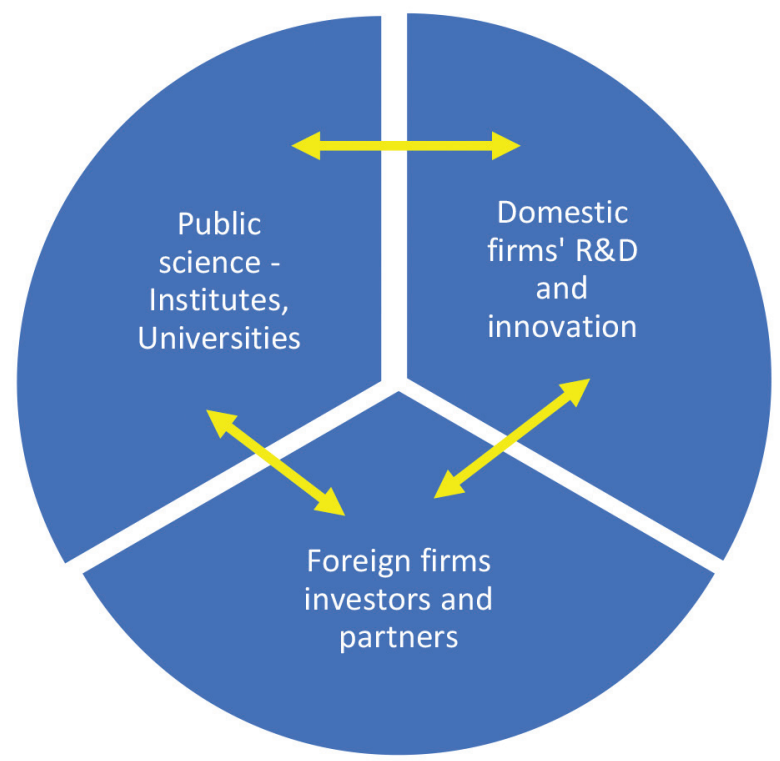

Source; Radosevic, 2021, Science industry links chapter: UNECE Innovation Capacity Report: Moldova, forthcoming

Figure 3 suggests that not only links between domestic firms and public research organisations matter, but even more so the links between domestic and foreign firms and links of universities with foreign firms and international sources of knowledge. As countries are upgrading, the nature of the relationship between science and industry is changing. In the initial stages, links with FDI are crucial, but as countries gradually upgrade, the relations between domestic firms and domestic R\&D organisations become more important.

In continuation, we illustrate the strength and intensity of each of three helices in the case of the CEE economies, including Western Balkan.

A subjective assessment of the intensity of university-industry R\&D collaboration through WEF Global Competitiveness Reports shows on a scale of 1-7 (best) a relatively high university-industry collaboration evaluation in $\mathrm{BiH}$ compared to other Western Balkan economies, Serbia and Croatia. How do we interpret this result? First, the individual indicator should be seen in the context of other indicators. Second, as pointed out earlier, the state of SIL can be understood only in the context of both firms' and 'academic' capabilities. 
Figure 4: Assessment of University-Industry R\&D Collaboration 2019 (scale 1-7)

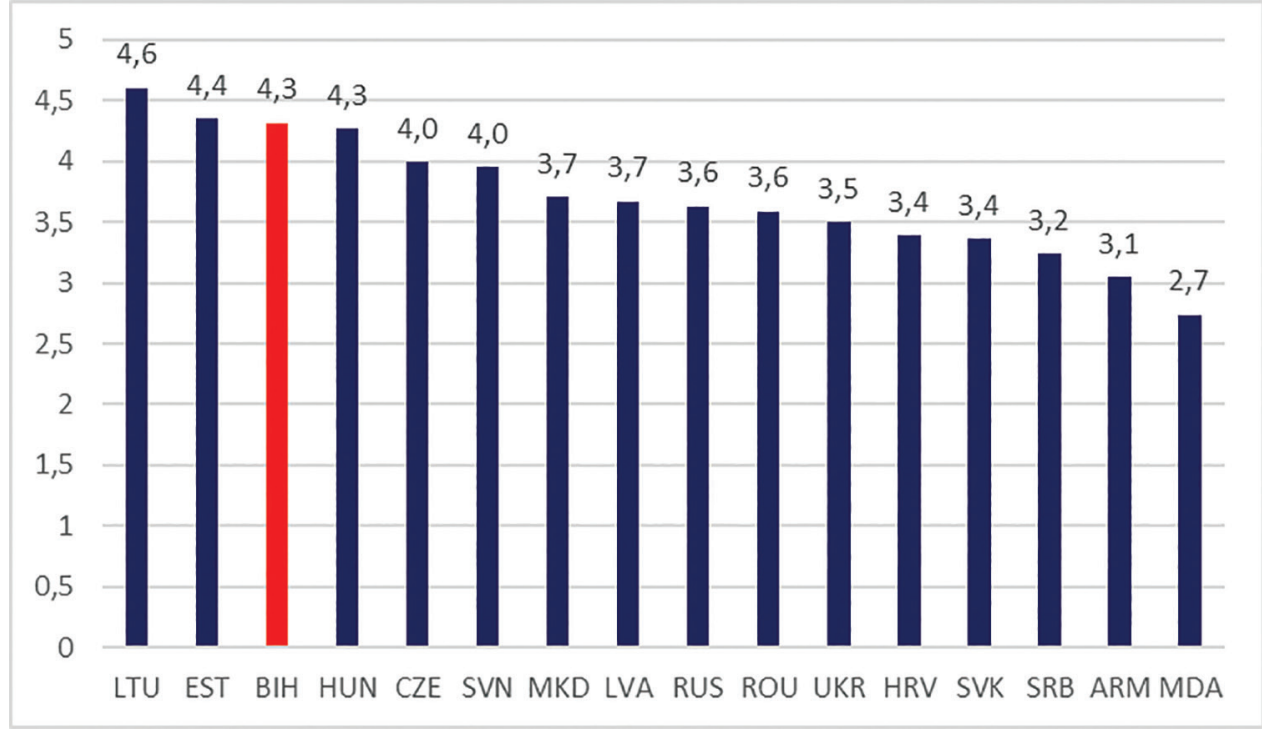

Source: WEF GCR

Figure 5 shows that the quality of science and research services and their availability is relatively low. Moreover, it seems that it is the worst when compared to all comparators in figure 5. This may suggest that the collaboration is comparatively better - given the state of both academic and business sector capabilities - than in other Western Balkan economies. However, in economic jargon, this collaboration can be described as a 'low-level equilibrium' collaboration. In other words, it takes place at very low levels of both academic and business sector R\&D and innovation activity. The following two figures support this hypothesis. 
Figure 5: Quality and availability of $R \& D$ services

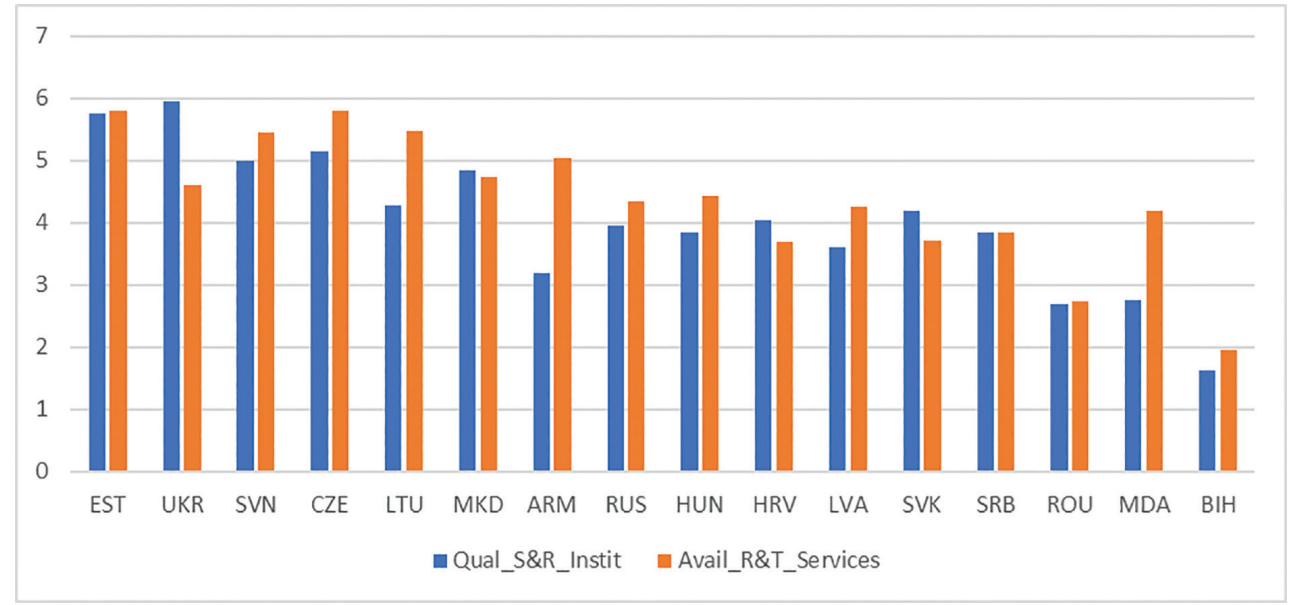

Source:WEF GCR

Figure 6 shows that the $\mathrm{R} \& \mathrm{D}$ intensity of the $\mathrm{BiH}$ economy is also the lowest among comparator economies. Its average R\&D intensity of only $0.2 \%$ and 656 researchers per $1 \mathrm{mn}$ population indicate minimal investments, which are insufficient for adequate absorption of foreign knowledge, let alone for significant knowledge generation activities.

Figure 6: GERD expenditures in GDP and RSE per 1 mn pop 2019

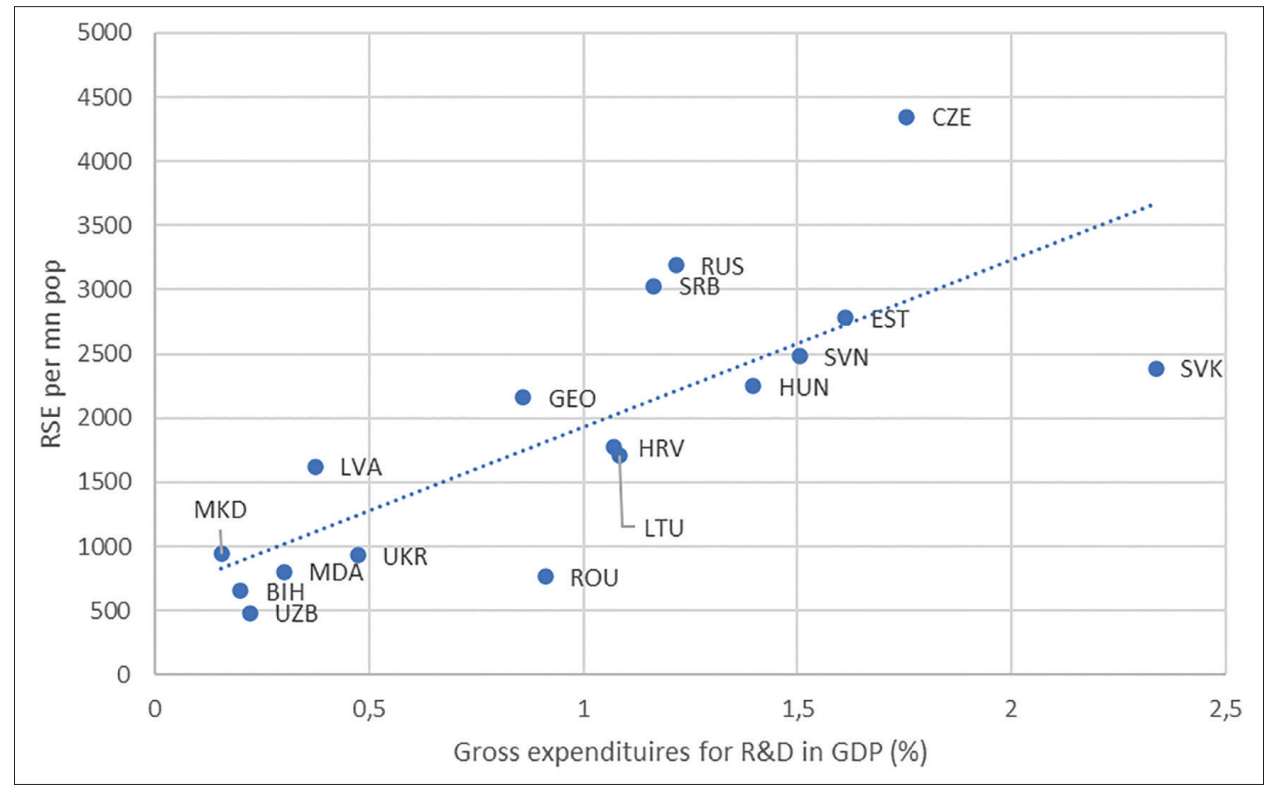

Source: Word Bank Development indicators database 
The second pillar of the Triple Helix innovation model is the business enterprise sector. Given the overall very low $\mathrm{R} \& \mathrm{D}$ expenditures in $\mathrm{BiH}$, we presume that the investment in the business sector is relatively marginal. This is further compounded by the dominance of small firms in economic structure, which as a rule do not have in-house R\&D capacities, and by deindustrialisation in the post-socialist period. So, on this basis, we cannot expect on upstream side demand for R\&D either internal (within the firm) or external (through extramural R\&D). However, we may expect possible demand-pull coming from downstream activities in firms i.e. activities related to improved production capability, quality and product differentiation.

ISO9000 certificates and trademark applications per $1 \mathrm{mn}$ population are imperfect but valuable proxies for this type of activities. A density of ISO9900 certificates of 172 per $1 \mathrm{mn}$ population places $\mathrm{BiH}$ in the bottom group of comparator economies. It is above the CIS economies, which are largely outside the global production networks, but is well below neighbouring and central European economies. This reflects very limited integration of $\mathrm{BiH}$ in the EU value chains where quality standards are one of the prerequisites. A situation is worse in terms of trademarks - a proxy of product differentiation on domestic and foreign markets. This may also reflect its economic structure in which there is a small share of consumer goods industries.

Figure 7: ISO900 certificates and trademarks per 1mn population 2015-19 avg

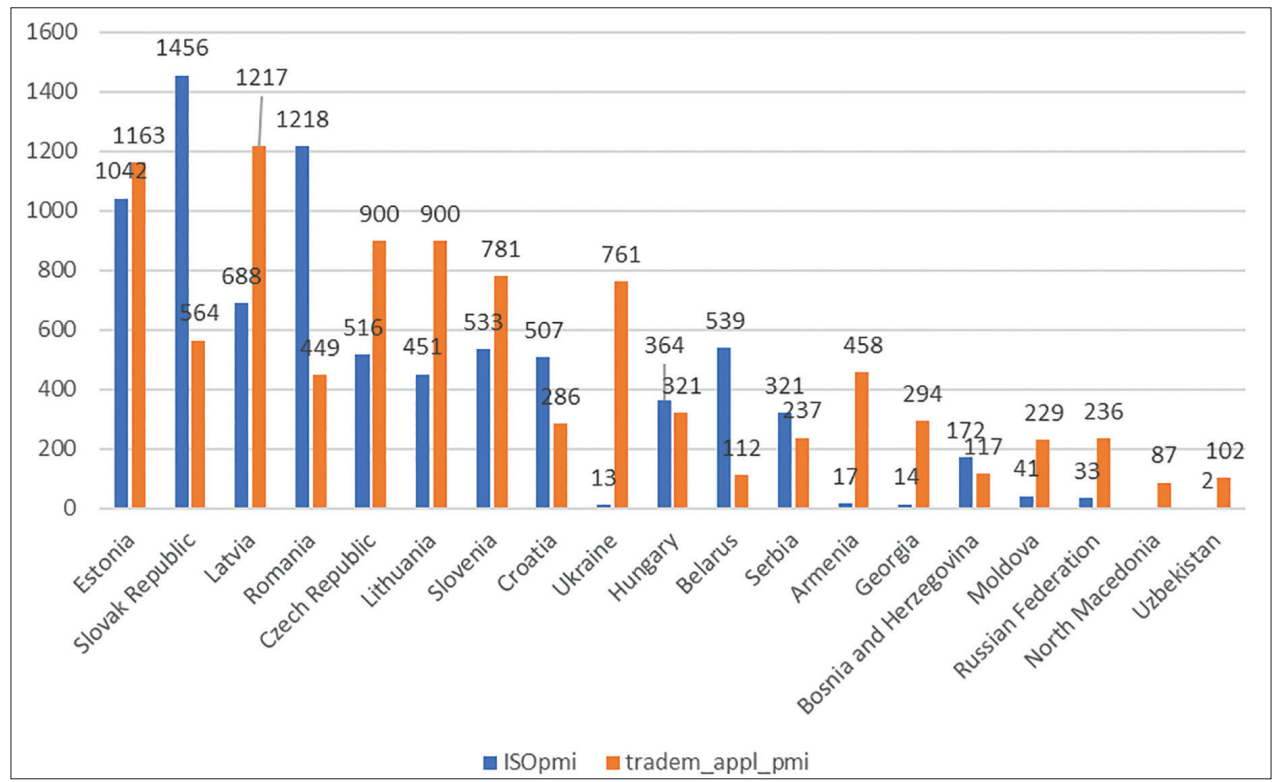

Source: ISO and WIPO Databases 
A key feature of competent firms are their organisational capabilities, by which we understand how people and resources are brought together to accomplish work within the enterprise. An organisational capability emerges from a series of connected activities within the firm, not from any single activity. There are no agreed proxies of organisational capabilities. As imperfect proxies, we use here two components that may shed some light on their levels of development: firm technology absorption capacity and control of international distribution. Figure 8 shows the assessment of each of these components for $\mathrm{BiH}$ and comparator economies jointly. $\mathrm{BiH}$ is ranked in the group at the bottom end. Its firms have low capabilities to absorb new technologies and depend on foreign partners to access international distribution channels. Both features will strongly shape the extent and the nature of SIL.

Figure 8: Assessment of firm technology absorption capacities and control of international distribution channels (WEF GCR 2019):

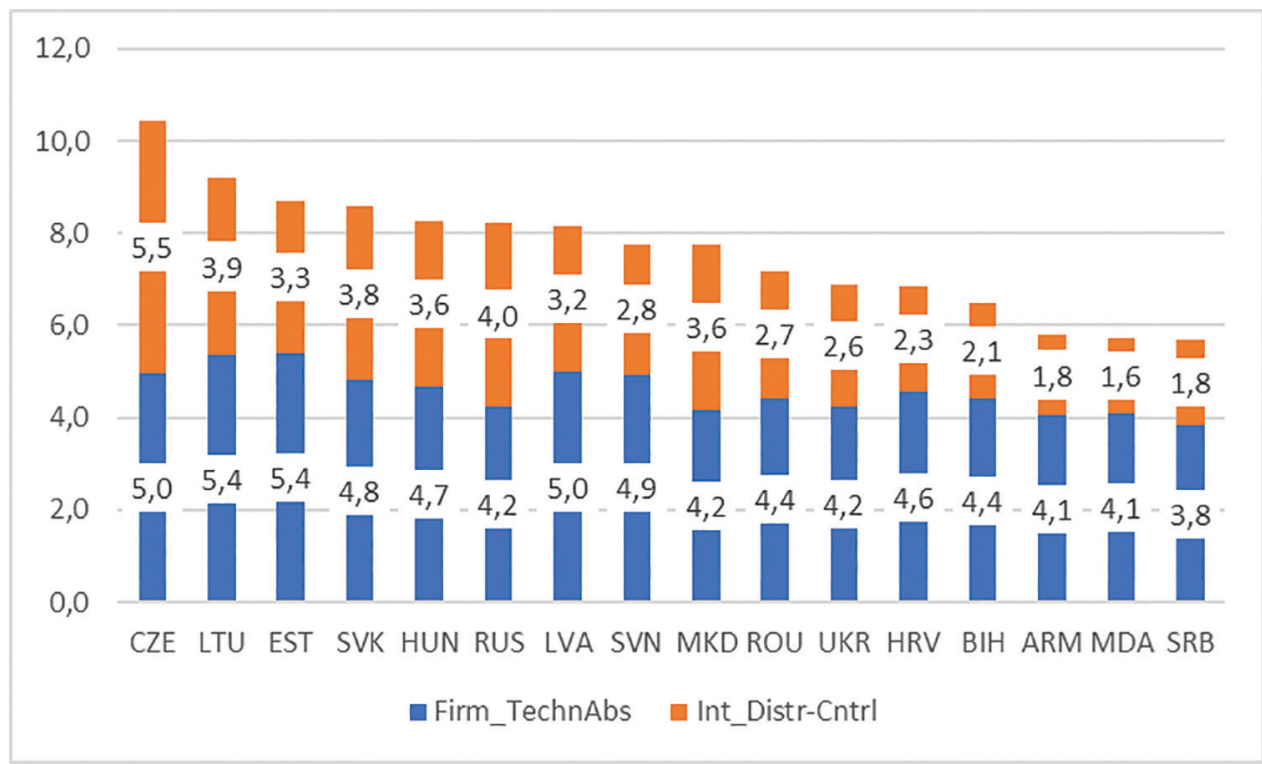

Source: WEF GCR

The third pillar of SIL in the catching-up economies is FDI, which is the primary source of new technologies and related knowledge. In an economy short of capital, new technology and limited access to foreign markets, foreign direct investments (FDI), subcontracting and other forms of knowledge are essential to technology upgrading, employment and export. Moreover, $\mathrm{BiH}$ is located close to central European economies, which is an excellent 
opportunity to join their industrial networks and get integrated into the EU supply chains.

If we use the share of net inflows in GDP as criteria, this potential for quick integration into the EU industrial networks has not yet been exploited. In relation to its comparators, $\mathrm{BiH}$ is in the group of economies 'discovered' by foreign investors post-2008. However, the overall share of inflows is still meagre (1.5\% of GDP in the $2015-19$ period).

Figure $8^{18}$ : FDI net inflows 2014-19 avg in \% of GDP

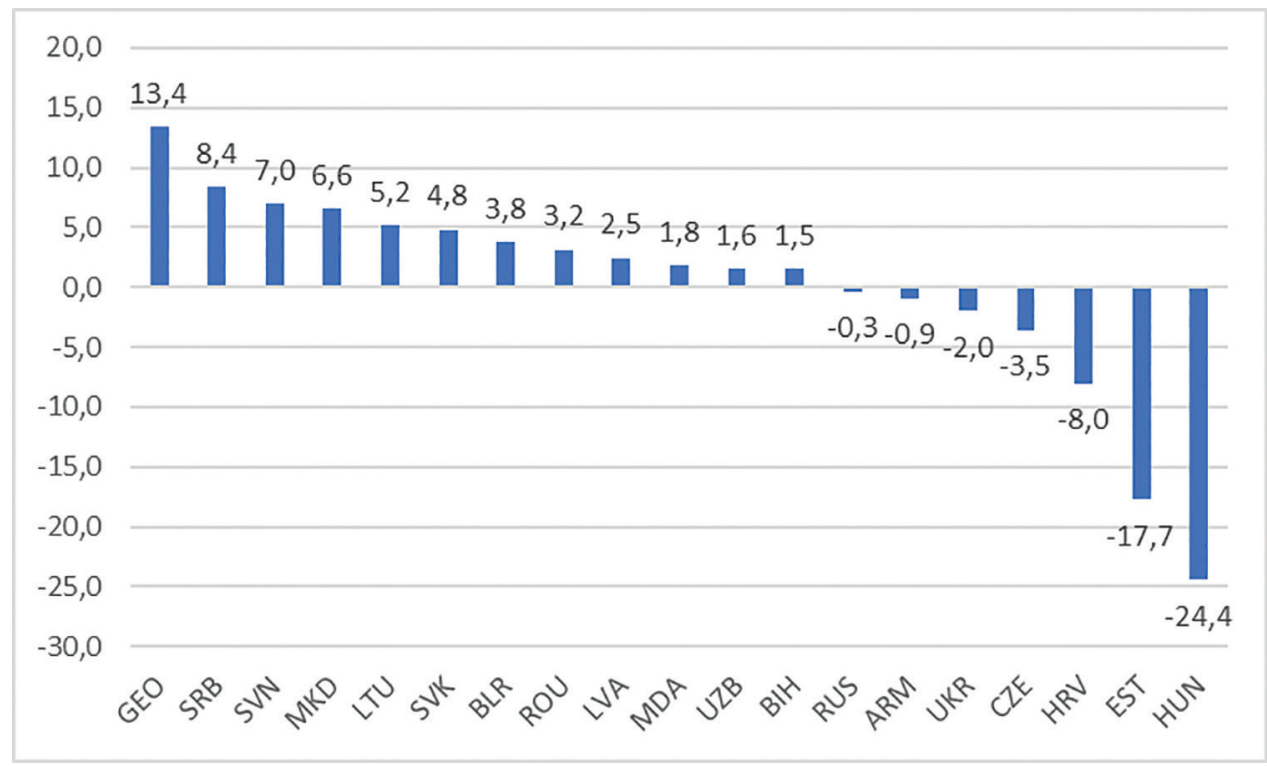

Source: World Bank Development Indicators database

An alternative route of acquiring foreign knowledge is purchasing foreign intellectual property rights through licences and other IPR (software etc.). This channel of knowledge acquisition is quite marginal in $\mathrm{BiH}$ and is at the level of $0.001 \%$ of GDP

In summary, our very unsystematic and quite imperfect evidence on three nodes of Triple Helix actors suggests that all three nodes are pretty weak, especially if we consider them in the conventional sense of R\&D based SIL. There are significant limits of the traditional view of SIL, where the R\&D sector operates as the primary source of knowledge and the business enterprise sector as a recipient. The key driver of the innovation process are enterprises,

\footnotetext{
${ }^{18} \mathrm{FDI}$ net inflows are the value of inward direct investment made by non-resident investors in the reporting economy.
} 
and the features of their innovation processes determine the extent and scope of cooperation with the R\&D sector. This leaves us with the question: What is the most productive framing of the SIL in the catching-up economies, like $\mathrm{BiH}$ ?

\section{Science industry links: implications for BiH}

Our conclusion on the above question boils down to one sentence: SIL should support technology upgrading and not (or not only) R\&D based growth. Elsewhere, we developed at greater length the technology upgrading as the appropriate framework for measuring and conceptualising technology development in catching-up economies (see Radosevic and Yoruk, 2016, 2018, 2019; Radosevic, 2017; Bruno et al., 2021).

The majority of enterprises in EU new member states (NMS) as well as in Western Balkans (WB) countries are 'non-R\&D innovators' (Arundel et al., 2008). Hence, to achieve growth and employment, the policy should not focus exclusively on encouraging $R \& D$ investment and supporting restructuring towards $\mathrm{R} \& \mathrm{R} \& \mathrm{D}$-intensive industries. More than half of enterprises in CEE countries innovate without investing in $R \& D$, and we can assume that this share is even higher in $\mathrm{BiH}$. Instead, its policy focus should much more address factors of production capability (quality, productivity, skills, engineering, software, knowledge intensive services, etc).

Accordingly, WB countries should aim to build policies that will foster these processes. Question is whether mainstream S\&T or innovation policy is a sufficient and necessary response to facilitate industry/technology upgrading in the WB region? We argue that mainstream innovation policy is a necessary but not sufficient ingredient to promote technology upgrading of WB economies. In these economies, $R \& D$ operates primarily as the factor of absorptive capacity rather than as the direct source of added value and employment.

The major challenge is how to kickstart industrial and technology upgrading, which is industry-specific. The knowledge base for such a process in the WB does not seem to be the major constrain. Parts of it already exist or are in the process to be generated through extensive foreign technical aid. For example, OECD (2010) study on sectoral competitiveness of several WB sectors has indicated upgrade paths for apparel, automotive suppliers and business process IT outsourcing (see below). The challenge is how to promote SIL, which can support these processes. 


\section{Patterns of industrial upgrading in Western Balkans in selected industries}

Apparel: from only CTM (42\%) services to the gradual introduction of Value Added services (OEM/OBM) + beyond imitation (design schools) Automotive suppliers: to move out of subcontracting 'cost trap' towards improved quality standards, design and supply chain management skills BPIT Outsourcing: from fragmented, diversified and local market-oriented firms towards the focus on core competencies (specialisation) and creation of BPITO champions

Source: Author based on OECD (2010)

\section{References}

Albuquerque, Eduardo Wilson Suzigan, Glenda Kruss, Keun Lee (eds) (2015) Developing National Systems of Innovation: University-Industry Interactions in the Global South, Edward Elgar, Cheltenham.

Arundel, A., C. Bordoy and M. Kanerva (2008), 'Neglected innovators: how do innovative firms that do not perform R\&D innovate? Results of an analysis of the Innobarometer 2007 survey No. 215', INNO-Metrics Thematic Paper

Arundel, A., Van de Paal, G., Soete, L., 1995. PACE Report: Innovation Strategies of Europe's Largest Firms: Results of the PACE Survey for Information Sources, Public Research, Protection of Innovations, and Government Programmes. Final Report, MERIT, University of Limburg, Maastricht

Bloom, N. and Van Reenen, J. (2010) Why Do Management Practices Differ across Firms and Countries? Journal of Economic Perspectives, Volume 24, Number 1, Winter 2010, p.203-224

Derek de Sola Price and Silvio A. Bedini, (1967) “Instrumentation," in Technology in Western Civilisation, ed.

Eduardo Albuquerque, Wilson Suzigan, Glenda Kruss, Keun Lee (eds) (2015) Developing National Systems of Innovation: University-Industry Interactions in the Global South, Edward Elgar, Cheltenham.

Glenda Kruss, Keun Lee, Wilson Suzigan, and Eduardo Albuquerque (2015) Introduction, In Albuquerque et al (2015) op. cit.

Griliches, Z. (1986). "Productivity, R\&D, and basic research at the firm level in the 1970s". American Economic Review 76, 141-154.

Jong-Hak Eun, Keun Lee, Guisheng Wu (2006) Explaining the "University-run enterprises" in China: A theoretical framework for university-industry relationship in developing countries and its application to China, Research Policy 35 (2006) 1329-1346

Lee, Jong Dong Lee, Slavo Radosevic, Dirk Meissner, Nick Vonortas) (eds) Technology Upgrading and Economic Catch-up, Oxford University Press

Levy, D., Terleckyj, N. (1989). "Problems identifying returns to R\&D in an industry". Managerial and Decision Economics 1-2, 43-49. 
Lichtenberg, F.R., Siegel, D.S. (1991). “The impact of R\&D investment on productivity-new evidence using linked R\&D-LRD data”. Economic Inquiry XXIX, 203-228.

Liefner, I., Schiller, D. (2008). Academic capabilities in developing countries - a conceptual framework with empirical illustrations from Thailand. Research Policy, 37, 276-293.

Lorenz, E. and Lundval, B. A. (2006) (eds) How European economies learn: coordinating competing models, Oxford University Press, Oxford.

Mansfield, E. (1980). "Basic research and productivity increase in manufacturing". American Economic Review 70, 863-873.

Mazzoleni Roberto and Richard R. Nelson (2007) Public research institutions and economic catch-up, Research Policy 36 (2007) 1512-1528

Melvin Kranzberg and Carroll W. Pursell, Jr. (Oxford: Oxford University Press).

Meyer-Krahmer, F., Schmoch, U., 1998. Science-based technologies: university-industry interactions in four fields. Research Policy 27, 835-851.

Nadiri, M.I., Mamuneas, T.P. (1994). "Effects of public infrastructure and R\&D capital on the cost structure and performance of US manufacturing industries". Review of Economics and Statistics 76 (1), 22-37.

OECD 2003 The Sources of Economic Growth in OECD Countries, Paris

OECD 2003 The Sources of Economic Growth in OECD Countries, Paris

Radosevic S. (2017) Upgrading technology in Central and Eastern European economies. IZA World of Labor: 338 doi: 10.15185/izawol.338

Radosevic Slavo and Esin Yoruk (2016) Why Do We Need Theory and Metrics of Technology Upgrading?, Asian Journal of Technology Innovation, Volume 24, 2016 - Issue sup1, http://dx.doi.org/10.1080/19761597.2016.1207415

Radosevic Slavo and Esin Yoruk (2018) Technology upgrading of middle-income economies: A new approach and Results, Technological Forecasting \& Social Change 129: pp. 56-75

Radosevic, S., M. Savic and R. Woodword (2010) Knowledge based entrepreneurship in central and eastern Europe: results of a firm level based survey, In Malerba, F. (ed) Knowledge-Intensive Entrepreneurship and Innovation Systems, Routledge, p.198-218

Radosevic, Slavo Deniz E. Yoruk and Esin Yoruk (2019) Technology Upgrading and Growth In Central and Eastern Europe, Chapter 8 in Social and Economic Development in Central and Eastern Europe. Stability and Change after 1990 Edited By Grzegorz Gorzelak, Routledge, London

Randolph Luca Bruno, Kirill Osaulenko and Slavo Radosevic (2021) Technology Upgrading in Emerging Economies: A New Approach to its Measurement, Results and Relationship to Mainstream Measures, In Lee et al, Oxford UNiversitry Press

Schmoch, U., 1997. Indicators of the relations between science and technology. Scientometrics 38: 1., 103-116.

Sveikauskas Leo 2007 R\&D and Productivity Growth: A Review of the Literature, Bureau of Labor Statistics Working Paper 408 